\title{
Live benthic diatoms from the upper continental slope: extending the limits of marine primary production
}

\author{
Dorien McGee ${ }^{1}$, Richard A. Laws ${ }^{2}$, Lawrence B. Cahoon ${ }^{3, *}$ \\ ${ }^{1}$ Department of Geology, University of South Florida, Tampa, Florida 33620, USA \\ ${ }^{2}$ Department of Geography and Geology, University of North Carolina Wilmington, Wilmington, \\ North Carolina 28403-5944, USA \\ ${ }^{3}$ Department of Biology and Marine Biology, University of North Carolina Wilmington, Wilmington, \\ North Carolina 28403-5915, USA
}

\begin{abstract}
Discovery of obligate benthic diatoms living as deep as $191 \mathrm{~m}$ substantially extends the known depth range of these primary producers and holds significant implications for oceanic productivity and biogeochemical cycling. Species of the epipsammic, monoraphid genus Cocconeis dominated the $\geq 35$ species of living benthic diatoms identified from the North Carolina continental margin in samples collected at bottom depths from 67 to $191 \mathrm{~m}$. A total of 126 species were identified from prepared samples, more than $90 \%$ of which are obligate benthic forms. Mid-day, near bottom, photosynthetically active radiation values recorded at the $191 \mathrm{~m}$ site averaged $0.106 \mu \mathrm{mol}$ photons $\mathrm{m}^{-2} \mathrm{~s}^{-1}$, representing about $0.028 \%$ of surface incident radiation and resulting from a water column attenuation coefficient of $0.0446 \mathrm{~m}^{-1}$. The presence of active benthic microalgae in these extremely low light conditions suggests the development of special light-harvesting adaptations including elevated levels of the blue-light absorbing accessory pigment, fucoxanthin. Extending the limit of benthic microalgal production to upper slope depths offshore from North Carolina increases the estimated total benthic primary production in that area of the continental margin by about $14 \%$. At present, extrapolating potential increases in benthic microalgal biomass and production resulting from extending the depth limits of viable benthic microalgae to a larger, global, oceanic scale is limited by paucity of data.
\end{abstract}

KEY WORDS: Diatoms $\cdot$ Benthos $\cdot$ Continental slope $\cdot$ Light flux $\cdot$ Pennales

\section{INTRODUCTION}

The volume of the world's oceans capable of supporting primary production remains to be firmly established, thus limiting our ability to model accurately important biogeochemical processes, including the biological oceanic carbon pump and oceanic productivity harvestable by humans. Recent studies in deep, poorly illuminated habitats substantially extend the known depth ranges and photosynthetic capabilities of the oceanic primary producer community compared with older notions of the limits of the euphotic zone, compensation depth and compensation light intensity. The depth receiving $1 \%$ of surface incident radiation has typically been cited as the average compensation depth and the lower limit of the euphotic zone, although deviations from this figure to as low as $0.1 \%$ surface incident radiation are acknowledged (Falkowski 1988, Falkowski \& Raven 1997). Some oceanic phytoplankton populations, in particular Prochlorococcus, are now known to grow at depths of 120 to $160 \mathrm{~m}$, at light fluxes averaging $0.04 \%$ $(0.02 \% \pm \mathrm{SD})$ of surface incident radiation, and to display exceptional photosynthetic efficiencies, $\alpha^{\mathrm{B}}$, averaging $0.107 \mathrm{mgC}$ (mg chlorophyll [chl] a) ${ }^{-1} \mathrm{~h}^{-1}$ ( $\mu \mathrm{mol}$ photons $\left.\mathrm{m}^{-2} \mathrm{~s}^{-1}\right)^{-1}$, biomass-normalized photo- 
synthetic rates, $P^{\mathrm{B}}$, between 0.48 and $3.84 \mathrm{mgC}$ $(\mathrm{mg} \mathrm{chl} \mathrm{a})^{-1} \mathrm{~h}^{-1}$, and saturating light intensity, $\mathrm{E}_{\mathrm{k}}$, as low as $9.2 \mu \mathrm{mol}$ photons $\mathrm{m}^{-2} \mathrm{~s}^{-1}$ (Johnson et al. 1999, 2002). Benthic macroalgae, although limited to neritic zones in the ocean, have demonstrated a similar ability to colonize relatively deep, poorly illuminated substrates (Markager \& Sand-Jensen 1992). Foliose macroalgae have been reported down to $157 \mathrm{~m}$ and $0.06 \%$ surface incident radiation, and crustose forms down to $268 \mathrm{~m}$ and $0.0005 \%$ surface incident radiation (Littler et al. 1985, Markager \& Sand-Jensen 1992).

Much less is known, however, about the ecological limits of another assemblage of primary producers important in neritic oceanic ecosystems, the benthic microalgae, particularly the limits of their depth distribution, adaptation to low light levels and, therefore, their depth and geographical ranges in the global ocean. Few measurements of benthic microalgal production at depths below $20 \mathrm{~m}$, very few records of benthic microalgal chl $a$ at depths below $60 \mathrm{~m}$, and only 2 reports from below $100 \mathrm{~m}$ worldwide are published (Cahoon 1999). Limited field studies of benthic microalgae distributions, and assessments of their photophysiology under low light conditions (Steele \& Baird 1968, Brotas \& Catarino 1995, MacIntyre \& Cullen 1995, Meyercordt \& Meyer-Reil 1999, Cahoon 1999, 2006, Kühl et al. 2001), suggest the potential for depth and light limits similar to those of phytoplankton and benthic macroalgae. Several lines of evidence suggested that a productive benthic microflora might be present at substantial depths offshore from North Carolina, USA. A distinctly benthic microalgal assemblage containing $>100$ epipsammic and epipelic diatom species to depths of $35 \mathrm{~m}$ off the coast of North Carolina was described by Cahoon \& Laws (1993). Significant concentrations of chemically intact chl a have been reported from sediments in outer shelf and upper slope habitats in several locations globally and, offshore from North Carolina, to depths as great as 222 m (Table 1, Fig. 1; Cahoon et al. 1990, 1992, Cahoon 1999). The presence of culturable diatoms and intact chl a to depths of $2000 \mathrm{~m}$ off Cape Hatteras (Cahoon et al. 1994) suggested at least the potential of benthic microalgae originating in shallower depths to colonize deep benthic habitats. Previous studies also indicated the potential for photophysiological adaptation to very low light fields dominated by shorter wave lengths at depth (Cahoon et al. 1992). Estimates of light flux in waters offshore from North Carolina using surface and bottom incident irradiation (Cahoon \& Cooke 1992), and a $0.1 \%$ light level minimum for net autotrophic production (Falkowski 1988), predicted that benthic microalgal growth could occur to depths of $90 \mathrm{~m}$ (Cahoon \& Laws 1993), below which benthic microalgae would disappear or enter into a resting spore stage. However, until now we were unable to document the presence of living vegetative cells of obligate benthic microalgae (epipsammic and epipelic diatoms) in outer shelf or upper slope habitats. This study investigated the taxonomic composition and depth distribution of benthic diatoms from continental margin sediments in Onslow Bay of the Atlantic coast offshore from North Carolina at depths of 67 to $191 \mathrm{~m}$ (Fig. 1). Extending the distribution limits of benthic microalgae within continental margin habitats will have significant implications for understanding oceanic production and biogeochemical cycles.

\section{MATERIALS AND METHODS}

Remotely operated vehicle (ROV) and CTD sampling instruments were deployed in Onslow Bay in October 2003 from RV 'Cape Hatteras' to sample water column properties and sediments, respectively, along 2 transects: (1) a $3.93 \mathrm{~km}$ long transect ('2003 I') of 8 sites on the outer shelf starting $96 \mathrm{~km}$ from shore $\left(33^{\circ} 12.730^{\prime} \mathrm{N}, 77^{\circ} 22.499^{\prime} \mathrm{W}\right)$ at depths between 67 and $121 \mathrm{~m}$, and (2) a $9.75 \mathrm{~km}$ long transect ('2003 II') of 6

Table 1. Distribution of benthic microalgal chl a (means or ranges) versus depth in coastal sediments at depths $\geq 40 \mathrm{~m}$ from previous studies

\begin{tabular}{|c|c|c|c|}
\hline $\begin{array}{l}\text { Depth } \\
\text { (m) }\end{array}$ & $\begin{array}{c}\mathrm{Chl} \mathrm{a} \mathrm{(SD)} \\
\left(\mathrm{mg} \mathrm{m}^{-2}\right)\end{array}$ & Location & Source \\
\hline 40 & $60-360$ & McMurdo Sound, Antarctica & Dayton et al. (1986) \\
\hline 40 & $57-219$ & Seranilla Bank & Bunt et al. (1972) \\
\hline 40 & 9.9 & Nosy-Bé, Madagascar & Plante-Cuny (1978) \\
\hline 41 & $25.1(13.1)$ & North Carolina, USA & Cahoon \& Cooke (1992) \\
\hline 41.3 & $6.4-15.3$ & Long Island Sound, USA & Sun et al. (1994) \\
\hline 45 & $18.5(9.9)$ & North Carolina, USA & Cahoon et al. (1992) \\
\hline 55 & 10.4 & Nosy-Bé, Madagascar & Plante-Cuny (1978) \\
\hline 60 & $27-39$ & Key Biscayne, USA & Bunt et al. (1972) \\
\hline 60 & 17 & Discovery Bay, Jamaica & Bunt et al. (1972) \\
\hline 60 & 16.4 & Nosy-Bé, Madagascar & Plante-Cuny (1978) \\
\hline 63 & $36.2(18.8)$ & North Carolina, USA & Cahoon et al. (1992) \\
\hline 83 & 30.4 & Nosy-Bé, Madagascar & Plante-Cuny (1978) \\
\hline 96 & $10.6(6.3)$ & North Carolina, USA & Cahoon et al. (1992) \\
\hline 114 & $22.1(5.0)$ & North Carolina, USA & Cahoon et al. (1992) \\
\hline 131 & $8.8(6.9)$ & North Carolina, USA & Cahoon et al. (1992) \\
\hline 142 & 15 & North Carolina, USA & Cahoon et al. (1990) \\
\hline 157 & $9.2(10.3)$ & North Carolina, USA & Cahoon et al. 1992) \\
\hline 194 & $4.4(3.6)$ & North Carolina, USA & Cahoon et al. (1992) \\
\hline 222 & $1.5(1.3)$ & North Carolina, USA & Cahoon et al. (1992) \\
\hline
\end{tabular}




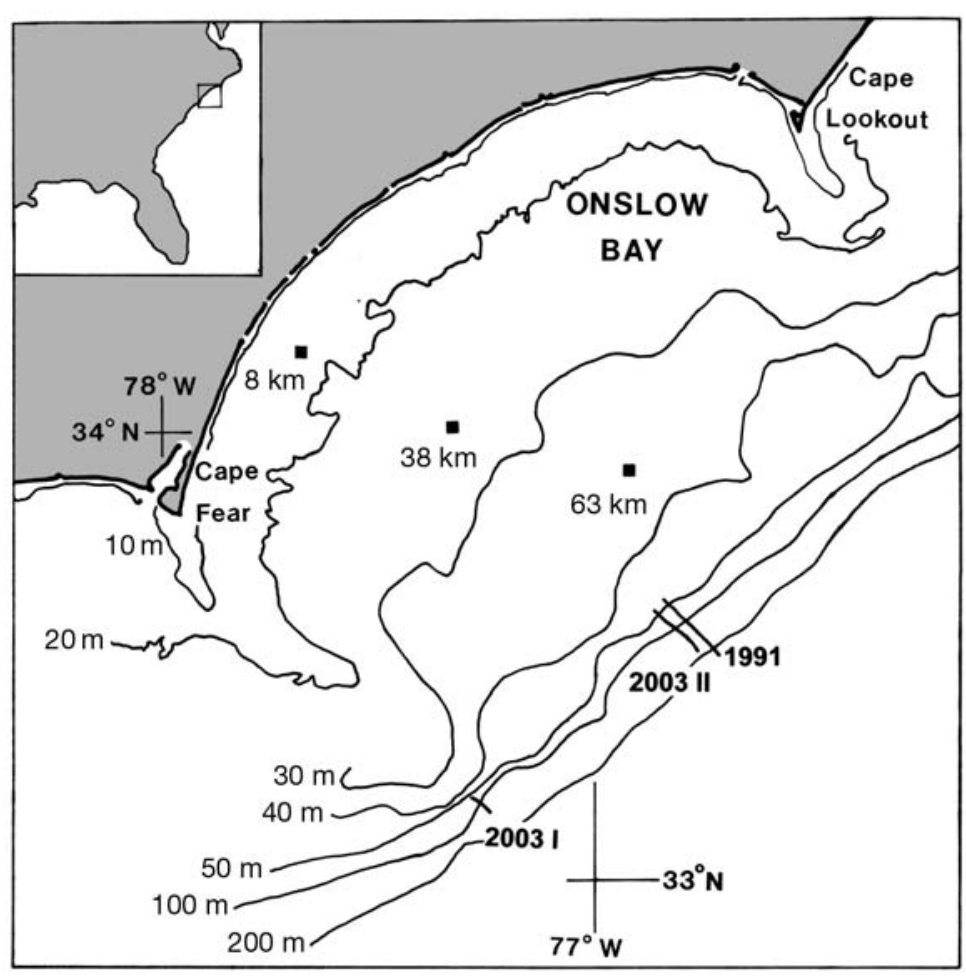

Fig. 1. Location of sampling sites in Onslow Bay, North Carolina, showing 1989 sites from which benthic microflora taxonomic composition was determined $(8,38$ and $63 \mathrm{~km}$ sites at depths of 20,33 and $35 \mathrm{~m}$, respectively; Cahoon \& Laws 1993. Depth contour positions are approximate), 1991 ROV transect yielding chl $a$ and pigment composition data (depth range: 45 to $222 \mathrm{~m}$; Cahoon et al. 1992), and 2003 transects (I and II; this study). Inset shows study area in southeastern USA

We used a SuperPhantom II ROV equipped with a Tri-Scoop 1000 rotary sampler (Brown et al. 1992) and real-time video control of sample collection activities for site selection and sediment sampling activities. The Tri-Scoop 1000 sampler collected surface sediment samples of approximately $300 \mathrm{ml}$ in volume and $5 \mathrm{~cm}$ in depth in 3 separate automatically closing sample cups at up to 3 locations 10 to $100 \mathrm{~m}$ apart per dive. Once on board, sediment samples from properly sealed sample cups were taken directly into the shipboard laboratory for microscopic examination using bright field microscopy to determine the presence of live diatom cells (defined as cells containing visible chloroplasts and/or exhibiting motility). Subsamples of sediment from all 14 sites were placed in screw-cap bottles, wrapped in aluminum foil, and kept refrigerated until examined further in the shore-based laboratory. Species identification and enumeration of live diatom cells were conducted at the shore-based laboratory immediately following the conclusion of the cruise approximately $48 \mathrm{~h}$ after collection of the last sample.

Wet slides were prepared from refrigerated raw sediment samples from each site and all live diatom cells were identified. Live cells were counted from Sites 1

sites on the outer shelf to upper slope starting $111 \mathrm{~km}$ from shore $\left(33^{\circ} 36.275^{\prime} \mathrm{N}, 76^{\circ} 51.797^{\prime} \mathrm{W}\right)$ at depths between 93 and $191 \mathrm{~m}$ (Fig. 1, Table 2). Each ROV deployment or dive represents a sampling site, and each ROV deployment was accompanied by a CTD cast. Two sites (3 and 4) were duplicate adjacent locations that were sampled by ROV, but not with separate CTD casts. Vertical profiles of conductivity (converted to salinity in psu), temperature $\left({ }^{\circ} \mathrm{C}\right)$, depth $(\mathrm{m})$ and light flux (photosynthetically active radiation [PAR], 400-750 nm, as $\mu \mathrm{mol}$ photons $\mathrm{m}^{-2} \mathrm{~s}^{-1}$ ) were measured at each site using a SeaBird SBE 911plus CTD with a Paroscientific digiquartz pressure transducer (accuracy $\pm 0.008 \%$ ) and a Biospherical QSP-200L $4 \pi$ PAR sensor at a scan rate of $24 \mathrm{~Hz}$. The CTD casts were halted $\sim 5$ to $10 \mathrm{~m}$ from the bottom, so actual bottom depths at sampling sites were obtained from the pressure sensor mounted on the ROV (accuracy $\pm 0.25 \%$ ). Light attenuation coefficients, $k$, were calculated using averaged surface $\left(<2 \mathrm{~m}\right.$ depth) PAR values, $I_{0}$, obtained while the CTD was equilibrated prior to descending and from averaged PAR values, $I_{d}$, at its maximum depth, $d$, and the formula $k=\ln \left(I_{d} / I_{0}\right) / d$. and 14. Representative live cells of each species were photographed using a Nikon Coolpix 995 digital camera affixed to an Olympus $\mathrm{BH} 2$ microscope at

Table 2. ROV sampling site depths and locations in Onslow Bay, North Carolina, October 2003

\begin{tabular}{|lccc|}
\hline $\begin{array}{l}\text { Date } \\
\text { Site no. }\end{array}$ & $\begin{array}{c}\text { Depth } \\
(\mathrm{m})\end{array}$ & $\begin{array}{c}\text { Latitude } \\
(\mathrm{N})\end{array}$ & $\begin{array}{c}\text { Longitude } \\
(\mathrm{W})\end{array}$ \\
\hline $\begin{array}{l}\text { 16 October 2003 } \\
1\end{array}$ & & & \\
2 & 69.8 & $33^{\circ} 12.730^{\prime}$ & $77^{\circ} 22.499^{\prime}$ \\
3 & 73.7 & $33^{\circ} 11.700^{\prime}$ & $77^{\circ} 23.107^{\prime}$ \\
4 & 82.6 & $33^{\circ} 11.501^{\prime}$ & $77^{\circ} 23.325^{\prime}$ \\
5 & 79.9 & $33^{\circ} 11.456^{\prime}$ & $77^{\circ} 23.54^{\prime}$ \\
6 & 91.8 & $33^{\circ} 11.102^{\prime}$ & $77^{\circ} 25.109^{\prime}$ \\
7 & 89.0 & $33^{\circ} 11.123^{\prime}$ & $77^{\circ} 25.257^{\prime}$ \\
8 & 102.4 & $33^{\circ} 10.906^{\prime}$ & $77^{\circ} 24.680^{\prime}$ \\
17 October 2003 & 121.0 & $33^{\circ} 10.551^{\prime}$ & $77^{\circ} 23.882^{\prime}$ \\
9 & & & \\
10 & 93.6 & $33^{\circ} 36.275^{\prime}$ & $76^{\circ} 51.797^{\prime}$ \\
11 & 104.8 & $33^{\circ} 35.829^{\prime}$ & $76^{\circ} 51.589^{\prime}$ \\
12 & 114.9 & $33^{\circ} 35.425^{\prime}$ & $76^{\circ} 51.331^{\prime}$ \\
13 & 122.6 & $33^{\circ} 34.813^{\prime}$ & $76^{\circ} 51.178^{\prime}$ \\
14 & 133.5 & $33^{\circ} 34.077^{\prime}$ & $76^{\circ} 50.702^{\prime}$ \\
& 191.2 & $33^{\circ} 32.801^{\prime}$ & $76^{\circ} 47.401^{\prime}$ \\
\hline
\end{tabular}


$1250 \times$ magnification. Live diatom species are notoriously difficult to identify to species level because the diagnostic morphology of the silica frustule is obscured by cytoplasm. Live diatom species were identified based on size, shape, observable frustule morphology and position of plastids within each cell. In addition, photographs of live cells were compared with light and scanning electron photomicrographs of cleaned specimens from the same samples. We relied on monographs by Hustedt (1955), Hendey (1964), John (1983), and Round et al. (1990) to assist with identifications.

A portion of each sample was processed to produce cleaned material for species identification by light and scanning electron microscopy (SEM). We placed $5 \mathrm{~cm}^{3}$ of each sediment sample in $50 \mathrm{ml}$ deionized water to which $10 \mathrm{ml}$ of $30 \%$ hydrogen peroxide and $0.1 \mathrm{~g}$ potassium dichromate were added to remove organic matter. Following 3 rinses with deionized water, $7 \mathrm{ml}$ of $37 \% \mathrm{HCl}$ were added to the sample along with $50 \mathrm{ml}$ of supernatant to remove carbonates. Following the reaction each sample was rinsed again 3 times with deionized water, diluted to $400 \mathrm{ml}$ total volume, stirred thoroughly and split for light microscope or SEM preparation.

Cover slip preparation of sediment suspensions for light microscope slides followed the settling technique of Laws (1983). Three $22 \mathrm{~mm}$ cover slips were made for each sample. The prepared cover slips were mounted on slides using a naphrax/toluene solution and progressively heated until evaporation of the toluene was complete. Excess naphrax was pressed out to remove bubbles and scraped off. Light microscope slides were examined at $1250 \times$ using ribbon transects traversing the entire cover slip and cell counts were done using the ribbon counting method described in Laws (1983). Photographs were taken at magnifications necessary to distinguish the morphological features of individual diatom species, and identifications were made using the monograph references cited previously. Measurements of frustule dimensions (length along apical, trans-apical, and pervalvar axes) and observations of frustule ornamentation were made for 5 species of pennate diatoms identified as living at these deep sites for comparison with frustule morphometrics of the same species sampled from intertidal habitats in a previous study (Hilterman 1998).

SEM mounts were prepared by vacuum-filtering a portion of each cleaned sample through one Whatman 5 um Millipore ${ }^{\circledR}$ cellulose nitrate membrane disc and 2 Whatman $0.4 \mu \mathrm{m}$ Millipore ${ }^{\circledR}$ cellulose nitrate membrane discs. Discs were dried for $24 \mathrm{~h}$ at $24^{\circ} \mathrm{C}$, cut into rectangular pieces and mounted on standard aluminum stubs. Three stubs were prepared with $0.4 \mu \mathrm{m}$ discs and one with a $5 \mu \mathrm{m}$ disc from each sample. Mounted stubs were sputter-coated with platinum palladium using a Cressington $208 \mathrm{HR}$ sputter coater and Cressington MTM 20 thickness controller to a thickness of $6 \mathrm{~nm}$. Samples were then viewed using a Philips 1L XL-305 FEG SEM. Twenty-one ribbon transects were analyzed at $1250 \times$ on each SEM stub to determine taxonomic content. Photographs and species identifications were performed at various magnifications on the SEM.

\section{RESULTS}

Real-time video imagery from ROV deployments demonstrated the presence of larger scale bottom features, including sand waves and ridges up to $1.3 \mathrm{~m}$ high oriented north-south at $122 \mathrm{~m}$ deep and east-west at $134 \mathrm{~m}$ deep, as well as various benthic macrofauna, including echinoderms, polychaetes, crustaceans and fishes. Near-bottom visibility as assessed from the ROV's video system consistently exceeded $20 \mathrm{~m}$. A sediment surface layer of microalgae could frequently be observed, particularly when sampling activities exposed lighter sub-surface sediment that contrasted with brown-colored microalgal growth. The substrate at shallower sites consisted of poorly sorted coarse-grained quartz sands and shell hash, gradually becoming finer with depth to well-sorted fine to very fine quartz sands and quartzose muds at the deepest sites.

Water clarity and light flux to the bottom were sufficient to provide adequate visibility for ROV operations at all but the deepest site, where artificial lighting

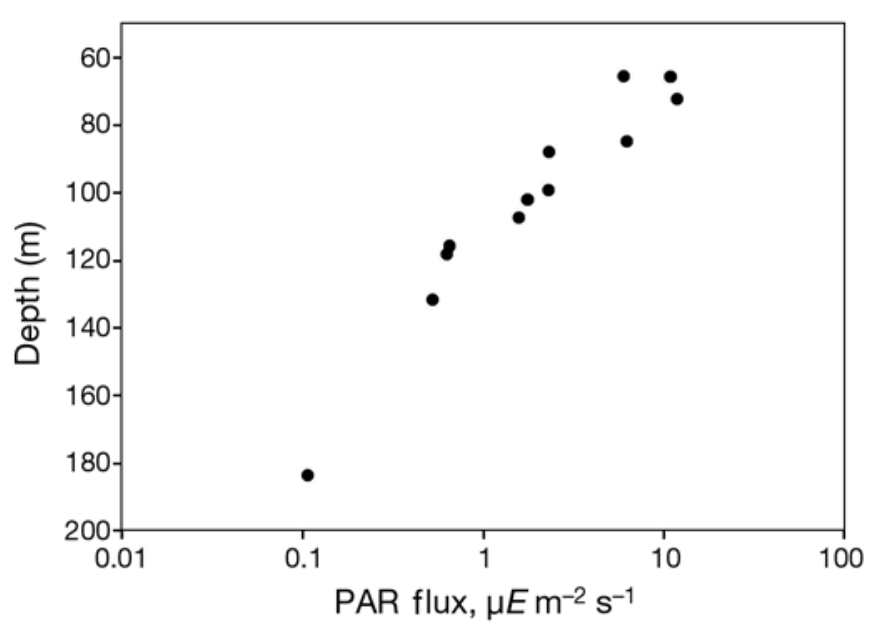

Fig. 2. Values of PAR observed (uncorrected for time of day effects on surface incident PAR flux) at near-bottom depths at each of 12 sites (excluding ROV Sites 4 and 5) in Onslow Bay, 16-17 October 2003 (transects 2003 I and 2003 II, Fig. 1). Linear regression yielded the relationship: $\log$ (near-bottom PAR $)=2.086-0.0177($ depth $) ; \mathrm{r}^{2}=0.925 ; F=123.9 ; \mathrm{df}=1,10$; $\mathrm{p}<0.0001$ 
became necessary. Attenuation coefficients $\left(k_{\mathrm{PAR}}\right)$ based on cast-average surface $(<2 \mathrm{~m}$ depth) and near-bottom irradiance values yielded estimates of $0.0497\left(4.97 \%\right.$ attenuation $\left.\mathrm{m}^{-1}\right)$ at the $67 \mathrm{~m}$ site, and $0.0446(4.46 \%$ attenuation $\mathrm{m}^{-1}$ ) at the $191 \mathrm{~m}$ site (Fig. 2). Measured light flux at the $183.5 \mathrm{~m}$ depth at the deepest location, ROV sampling site no. 14, was $0.106 \mu \mathrm{mol}$ photons $\mathrm{m}^{-2} \mathrm{~s}^{-1}$, approximately $0.028 \%$ of surface light flux. Surface conditions were calm with clear skies, and sampling operations took place during midmorning and mid-afternoon hours, probably yielding observed PAR flux values at or near their daily maxima for days of the year 289 to 290. Maximal PAR fluxes to the bottom at solar zenith or in mid-summer would probably have been somewhat higher than observed, but surface wave action or cloudiness would substantially lower those fluxes.

Living diatom cells were observed in sediment samples from all 14 sites upon shipboard microscopic analysis immediately following collection (Table 3, Fig. 3). We observed living cells of at least 35 species of diatoms in the raw sediment samples (Tables 3 \& 4). Ribbon counts of individual living cells from Sites 1 (shallowest) and 14 (deepest) showed that more than $99 \%$ were of obligate benthic species, most of which were pennate forms less than $30 \mu \mathrm{m}$ in length (Table 4). The obligate benthic, epipsammic genus Cocconeis (Fig. 3) comprised $77 \%$ of individual living cells recorded from Sites 1 and 14 (Table 4). Lesser numbers of living cells of the genera Fallacia and Amphora (Fig. 3), as well as Nitzschia and Navicula, were also found. We noted dormant or resting spores in several samples, but did not quantify these. Several specimens of Nitzschia and Navicula from the deepest site displayed characteristic directed linear motion parallel to the apical axis further attesting to the active live nature of this deep microflora. An online photographic archive of all living species observed can be found at http://dl.uncw.edu/digilib/biology/ protists/taxonomy $\% 20$ and $\% 20$ systematics/MEPS_ Diatoms/.

Analysis of diatom species in cleaned material from Sites 1 to 10 and Site 14 revealed 126 diatom species in at least 29 genera (Table 5). In Table 5 we categorize

\begin{tabular}{|c|c|}
\hline Site 1 (69.8 m) & Site 7 (102.4 m) \\
\hline Achnanthes cf. A. delicatula & Cocconeis cf. C. disculus \\
\hline Actinoptychus splendens & Cymatosira cf. C. belgica \\
\hline Amphora cf. A. coffaeaformis & Diploneis cf. D. aestuarii \\
\hline Cocconeis cf. C. disculus & Navicula sp. B \\
\hline Cocconeis cf. C. distans & Nitzschia cf. N. panduriformis \\
\hline Cocconeis cf. C. placentula & Nitzschia sp. B \\
\hline Fallacia cf. F. forcipata & Pleurosigma cf. P. distinguendum \\
\hline Navicula cf. $N$. digitoconvergens & Site 8 (121 m) \\
\hline Navicula sp. A & Diploneis sp. indeterminate \\
\hline Nitzschia cf. N. frustulum & Nitzschia sp. A \\
\hline $\begin{array}{l}\text { Nitzschia cf. N. hybridaeformis } \\
\text { Nitzschia cf. N. panduriformis } \\
\text { Nitzschia cf. N. pellucida }\end{array}$ & $\begin{array}{l}\text { Site } 9(\mathbf{9 3 . 6} \mathbf{~ m}) \\
\text { Campylosira sp. A } \\
\text { Cocconeis sp. A }\end{array}$ \\
\hline $\begin{array}{l}\text { Site } 2(\mathbf{7 3 . 7} \mathbf{~ m}) \\
\text { Actinocyclus sp. A } \\
\text { Cocconeis cf. C. disculus }\end{array}$ & $\begin{array}{l}\text { Diploneis cf. } D \text {. bombus } \\
\text { Pleurosigma sp. indeterminate } \\
\text { Nitzschia sp. indeterminate }\end{array}$ \\
\hline $\begin{array}{l}\text { Cocconeis cf. C. distans } \\
\text { Cymatosira lorenziana } \\
\text { Cymatosira cf. C. belgica } \\
\text { Grammatophora cf. G. marina } \\
\text { Paralia sulcata }\end{array}$ & $\begin{array}{l}\text { Site } 10(\mathbf{1 0 4 . 8} \mathbf{~ m}) \\
\text { Amphora sp. indeterminate } \\
\text { Cymatosira cf. C. lorenziana } \\
\text { Navicula sp. B } \\
\text { Nitzschia cf. N. panduriformis }\end{array}$ \\
\hline $\begin{array}{l}\text { Site } 3 \text { (82.6 } \mathbf{~ m}) \\
\text { Cymatosira cf. C. belgica } \\
\text { Diploneis cf. D. smithii } \\
\text { Coscinodiscus sp. A }\end{array}$ & $\begin{array}{l}\text { Site } 11(114.9 \text { m) } \\
\text { Navicula sp. A } \\
\text { Nitzschia sp. indeterminate } \\
\text { Paralia cf. P. sulcata }\end{array}$ \\
\hline $\begin{array}{l}\text { Site } 4(\mathbf{7 9 . 9} \mathbf{~ m}) \\
\text { Amphora cf. A. coffaeaformis } \\
\text { Cocconeis cf. C. disculus } \\
\text { Thalassiosira sp. A }\end{array}$ & $\begin{array}{l}\text { Site } 12(122.6 \mathbf{~ m}) \\
\text { Diploneis cf. D. aestuarii } \\
\text { Navicula sp. A }\end{array}$ \\
\hline $\begin{array}{l}\text { Site } 5(\mathbf{9 1 . 8} \mathbf{~ m}) \\
\text { Cocconeis cf. C. disculus } \\
\text { Cymatosira cf. C. belgica } \\
\text { Diploneis cf. D. aestuarii }\end{array}$ & $\begin{array}{l}\text { Site } \mathbf{1 3}(\mathbf{1 3 3 . 5} \mathbf{~ m}) \\
\text { Grammatophora cf. G. marina } \\
\text { Pleurosigma cf. P. marinum } \\
\text { Triceratium? sp. indeterminate }\end{array}$ \\
\hline Navicula sp. B & Site $14(191.2 \mathrm{~m})$ \\
\hline Nitzschia cf. N. hybridaeformis & Actinoptychus cf. A. splendens \\
\hline $\begin{array}{l}\text { Nitzschia cf. N. closterium } \\
\text { Nitzschia sp. A }\end{array}$ & Cocconeis cf. C. disculus \\
\hline $\begin{array}{l}\text { Nitzschia sp. A } \\
\text { Thalassiosira sp. B }\end{array}$ & $\begin{array}{l}\text { Diploneis cf. D. chersonensis } \\
\text { Navicula sp. A }\end{array}$ \\
\hline $\begin{array}{l}\text { Site } 6(\mathbf{8 9 . 0} \mathbf{~ m}) \\
\text { Diploneis } \mathrm{cf} . \text { D. aestuarii } \\
\text { Navicula sp. B } \\
\text { Nitzschia cf. N. panduriformis } \\
\text { Pleurosigma cf. P. distinguendum } \\
\text { Raphid pennate indeterminate }\end{array}$ & $\begin{array}{l}\text { Nitzschia cf. } N \text {. brevirostris } \\
\text { Nitzschia cf. } N \text {. closterium } \\
\text { Nitzschia cf. } N \text {. panduriformis }\end{array}$ \\
\hline
\end{tabular}

\section{Site $1(69.8 \mathrm{~m})$}

Actinoptychus splendens

Navicula cf. N. digitoconvergens

Nitzschia cf. $N$. frustulum

pellucida

Cisculus

Grammatophora cf. G. marina

Site $3(82.6 \mathrm{~m})$

Cymatosira cf. C. belgica

Amphora cf. A. coffaeaformis

Nitzschia sp. A

Diploneis cf. D. aestuarii

Pleurosigma cf. P. distinguend

Raphid pennate indeterminate

\author{
Site 7 (102.4 m) \\ Navicula sp. B \\ Nitzschia sp. B \\ Pleurosigma cf. P. distinguendum \\ Nitzschia sp. A \\ Site $9(93.6 \mathrm{~m})$ \\ Campylosira sp. A \\ Pleurosigma sp. indeterminate \\ Nitzschia sp. indeterminate \\ Navicula sp. B \\ Nitzschia cf. N. panduriformis \\ Nitzschia sp. indeterminate \\ Paralia cf. P. sulcata \\ Site 12 (122.6 m) \\ Navicula sp. A \\ Site 13 (133.5 m) \\ Grammatophora cf. G. marina \\ Pleurosigma cf. P. marinum \\ eratium? sp. indeterminate \\ Cocconeis cf. C. disculus \\ Navicula sp. A \\ Nitzschia cf. N. closterium \\ Nitzschia cf. $N$. panduriformis
}

all of the observed diatom taxa into 4 broad groups that have taxonomic and life-mode significance. These are (1) centric, which are largely planktonic or tychopelagic (alternately suspended and resting on the substrate); (2) araphid pennate, many of which are chain-forming and can be benthic, tychopelagic or planktonic ; (3) monoraphid pennate, most of which are epipsammic or epiphytic; and (4) biraphid pennate, which are typically epipelic and motile (see Table 5). Of all identified species 113 are obligate benthic pennate forms (epipsammic, epipelic, and/or epiphytic; Cahoon \& Laws 1993). At least 4 species found in cleaned and live material could be considered tycho- 

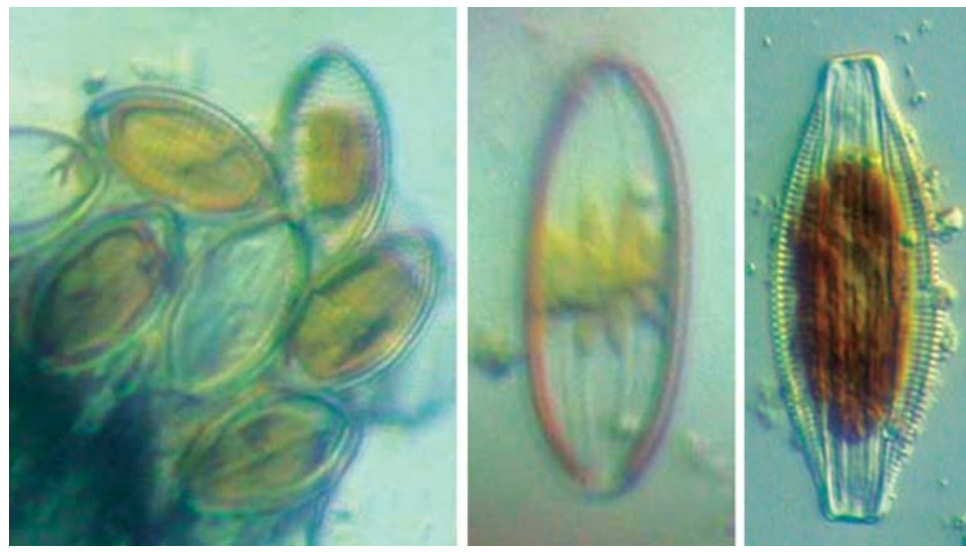

Fig. 3. (left to right) Cocconeis disculus (length $=$ ca. $16 \mu \mathrm{m}$ ), Fallacia forcipata $($ length $=24.5 \mu \mathrm{m}$ ) and Amphora coffaeaformis (length $=23.5 \mu \mathrm{m}$ ). All specimens photographed in white polarized light

pelagic, Cymatosira belgica, C. lorenziana, Grammatophora marina and Paralia sulcata. Actinoptychus splendens, a large robust centric species $(>50 \mu \mathrm{m}$ diameter), and several species of Coscinodiscus and/or Thalassiosira were the only planktonic diatoms noted, accounting for only $1 \%$ of the valves identified in cleaned material. Qualitative analysis of cleaned material also revealed that the obligate benthic, epipsammic genus Cocconeis constituted the largest number of valves observed in cleaned material. Qualitative analysis of valve density in both freshly collected raw material and cleaned material indicated that, although live diatoms and dead valves were found at all 14 sites, the density of live specimens and valves decreased with increasing depth.

A morphometric comparison of 5 species found live and relatively abundant at Sites 1 and 14 with specimens of the same species previously documented at 2 shallow intertidal sites (Hilterman 1998) was conducted to determine if deep water specimens showed significant morphological differences from their shallow water counterparts. The comparison showed that there were some significant morphometric differences between specimens of the same species sampled in the 2 different habitats, but no consistent patterns of size or shape that would distinguish the deep water organisms from the intertidal microflora (Table 6).

\section{DISCUSSION}

The presence of living obligate benthic diatoms in sediments extending into upper continental slope habitats is strong evidence that benthic primary productivity may be much more important than previously thought. Previous reviews assumed that productive benthic microalgae were limited to depths above 50 (Charpy-Robaud \& Sournia 1990) or $60 \mathrm{~m}$ (Cahoon 1999). The exceptional clarity of the continental margin waters off North Carolina, with strong influence from the Gulf Stream, contributes to the ability of benthic diatoms to grow at such great depths, but adaptation to exceptionally low light flux must also be considered. Given that we measured light fluxes at nearbottom depths under almost ideal conditions (calm seas with minimal surface albedo, clear sky, mid-day illumination), perhaps novel photo-adaptation genotypes and phenotypes may be expressed by diatoms living in these habitats.

Several factors indicate an autochthonous origin for benthic diatoms in North Carolina slope habitats, in addition to the distinctly benthic nature of this microflora. First, the dominant diatom genus, Cocconeis, found in the live and cleaned deep water material, is an obligate benthic epipsammic monoraphid form that permanently attaches to the surface of sand grains using adhesive mucus secreted through the raphe valve, so transport of this type of diatom requires movement of the sediment itself. Scarcity of planktonic forms at all 14 sites suggests that settling phytoplankton provide no significant inputs to the benthic assemblage. The physical forcing required to move even fine-grained sands from shallower waters into the deeper shelf/slope waters in Onslow Bay is rarely present except during major storms. Similarly, the relatively low frequency of tychopelagic forms in the deep microflora is not consistent with allochthonous inputs, as would be expected if physical forces drove significant transport from shallower habitats. Major storms that generate currents strong enough to move sand in this region typically only resuspend sediment by oscillatory near-bottom wave

Table 4. Live cell counts from sampling Sites 1 (67 m) and 14 $(191 \mathrm{~m})$

\begin{tabular}{|lcc|}
\hline Taxon & Site 1 & Site 14 \\
\hline Actinoptychus splendens & 0 & 2 \\
Amphora coffaeaformis & 24 & 0 \\
Cocconeis disculus & 359 & 36 \\
Cocconeis distans & 27 & 0 \\
Cocconeis placentula & 9 & 0 \\
Diploneis chersonensis & 0 & 3 \\
Navicula sp. A & 15 & 0 \\
Navicula digitoconvergens & 17 & 0 \\
Nitzschia frustulum & 6 & 0 \\
Nitzschia panduriformis & 36 & 18 \\
Nitzschia pellucida & 7 & 0 \\
Total & 500 & 59 \\
\hline
\end{tabular}


Table 5. Complete list and occurrence for all taxa identified in raw and cleaned materials. Abbreviations for cell morphology: C = centric, $\mathrm{AP}=$ araphid pennate, $\mathrm{MP}=$ monoraphid pennate, $\mathrm{BP}=$ biraphid pennate. Abbreviations for life habit: $\mathrm{p}=$ planktonic, uben = unspecified benthic, epsm = epipsammic, epel = epipelic, ephy = epiphytic, es/ep = epipsammic/epiphytic, tpl = tychopelagic

\begin{tabular}{|c|c|c|c|c|c|c|c|}
\hline \multirow{2}{*}{$\begin{array}{l}\text { Species } \\
\text { Achnanthes brevipes }\end{array}$} & Morphology & \multirow{2}{*}{$\begin{array}{c}\text { Life } \\
\text { habit } \\
\text { es/ep }\end{array}$} & \multirow{2}{*}{$\begin{array}{c}\text { Site no. } \\
4\end{array}$} & \multirow{2}{*}{$\begin{array}{l}\text { Species } \\
\text { Eunotogramma marinum }\end{array}$} & Morphology & \multirow{2}{*}{$\begin{array}{c}\text { Life } \\
\text { habit } \\
\text { epsm }\end{array}$} & \multirow{2}{*}{$\begin{array}{c}\text { Site no. } \\
2-7\end{array}$} \\
\hline & MP & & & & $\mathrm{C}$ & & \\
\hline A. delicatula & MP & es/ep & $1,2,5,8$ & E. rostratum & $\mathrm{C}$ & epsm & $2-7$ \\
\hline A. danica & MP & es/ep & 1,5 & Fallacia forcipata & $\mathrm{BP}$ & epel & $1,7,14$ \\
\hline A. hauckiana & MP & es/ep & $1,4,7,10$ & F. litoricola & $\mathrm{BP}$ & epel & $1,4,8$ \\
\hline A. kolbei & MP & es/ep & 1,6 & F. plathii & $\mathrm{BP}$ & epel & 3 \\
\hline A. manigera & MP & es/ep & 6 & F. vittata & $\mathrm{BP}$ & epel & 5 \\
\hline A. pseudobliqua & MP & es/ep & 3,8 & F. sp. A & $\mathrm{BP}$ & epel & 2 \\
\hline A. reidensis & MP & es/ep & 1,2 & F. sp. B & $\mathrm{BP}$ & epel & 5 \\
\hline A. taeniata & MP & es/ep & 3 & F. sp. C & $\mathrm{BP}$ & epel & 3 \\
\hline A. tenera & MP & es/ep & 1 & F. sp. D & $\mathrm{BP}$ & epel & 2,4 \\
\hline Actinocyclus sp. A & $\mathrm{C}$ & $\mathrm{p}$ & 2 & $F . \mathrm{sp} . \mathrm{E}$ & $\mathrm{BP}$ & epel & 3 \\
\hline Actinoptychus splendens & $\mathrm{C}$ & $\mathrm{p}$ & 1,14 & $F . s p . F$ & $\mathrm{BP}$ & epel & 2,5 \\
\hline Amphora beaufortiana & $\mathrm{BP}$ & epel & 1,2 & Fragilaria brevistriata & $\mathrm{AP}$ & uben & $2-4,6$ \\
\hline A. coffaeaformis & $\mathrm{BP}$ & epel & $1-4,8,14$ & F. hyalina & $\mathrm{AP}$ & uben & 2 \\
\hline A. costata & $\mathrm{BP}$ & epel & 4 & F. tabulata & AP & uben & $3,4,9$ \\
\hline A. delicatissima & $\mathrm{BP}$ & epel & 6 & $F$. sp. A & $\mathrm{AP}$ & uben & 1,2 \\
\hline A. exigua & $\mathrm{BP}$ & epel & 4,5 & F. sp. B & AP & uben & 1 \\
\hline A. granulata & $\mathrm{BP}$ & epel & $1-3$ & F. sp. C & $\mathrm{AP}$ & uben & 1 \\
\hline A. helenensis & $\mathrm{BP}$ & epel & 5,7 & F. sp. D & AP & uben & $1,4,5,7$ \\
\hline A. ovalis & $\mathrm{BP}$ & epel & $1-4$ & Grammatophora marina & $\mathrm{AP}$ & es/ep & $2-7,14$ \\
\hline A. pannucea & $\mathrm{BP}$ & epel & 5 & Lyrella sp. A & $\mathrm{BP}$ & epel & 3 \\
\hline A. pseudoholsatica & $\mathrm{BP}$ & epel & 3 & Mastogloia angusta & MP & epsm & 1 \\
\hline A. subcuneata & $\mathrm{BP}$ & epel & 1,2 & M. lanceolata & MP & epsm & 8 \\
\hline A. tenerrima & $\mathrm{BP}$ & epel & 2 & M. pseudoelegans & MP & epsm & 2 \\
\hline A. sp. A & $\mathrm{BP}$ & epel & 4 & Melosira moniliformis & $\mathrm{C}$ & $\mathrm{p}$ & $1-4$ \\
\hline A. sp. B & $\mathrm{BP}$ & epel & 3 & Navicula abunda & $\mathrm{BP}$ & epel & 1 \\
\hline A. sp. C & $\mathrm{BP}$ & epel & 2 & N. cancellata & $\mathrm{BP}$ & epel & 2,6 \\
\hline A. sp. D & $\mathrm{BP}$ & epel & 9 & N. digitoconvergens & $\mathrm{BP}$ & epel & 1 \\
\hline Biddulphia regina & $\mathrm{C}$ & $\mathrm{p}$ & 5,6 & N. diplonoides & $\mathrm{BP}$ & epel & 1,6 \\
\hline Biremis lucens & $\mathrm{BP}$ & epel & 1,2 & N. diversestriata & $\mathrm{BP}$ & epel & 1 \\
\hline Campylosira sp. A & $\mathrm{C}$ & epsm & 9 & N. ergadensis & $\mathrm{BP}$ & epel & 5 \\
\hline Cocconeis californica & MP & epsm & $1,3,5-7,9$ & N. humii & $\mathrm{BP}$ & epel & 1,7 \\
\hline C. convexa & MP & epsm & 1,6 & N. menisculus & $\mathrm{BP}$ & epel & 3,4 \\
\hline C. dirupta & MP & epsm & $1-4$ & N. muraliformis & $\mathrm{BP}$ & epel & 5 \\
\hline C. disculus & MP & epsm & $1-10,14$ & N. nummularia & $\mathrm{BP}$ & epel & $1,3-5$ \\
\hline C. distans & MP & epsm & $1,2,5-7,14$ & N. palpebralis & $\mathrm{BP}$ & epel & 6,10 \\
\hline C. distantula & MP & epsm & $1,3,5,8$ & N. paul-schulzii & $\mathrm{BP}$ & epel & $1,4,5$ \\
\hline C. granulifera & MP & epsm & 2,3 & N. reinhardtii & $\mathrm{BP}$ & epel & 6 \\
\hline C. hoffmanni & MP & epsm & $1,2,4$ & N. riparia & $\mathrm{BP}$ & epel & 2,5 \\
\hline C. peltoides & MP & epsm & 1,5 & N. subhamulata & $\mathrm{BP}$ & epel & 1 \\
\hline C. pinnata & MP & epsm & 2,6 & $N . \mathrm{sp} . \mathrm{A}$ & $\mathrm{BP}$ & epel & $1,9,11,12,14$ \\
\hline C. placentula & MP & epsm & $1,2,10$ & N. sp. B & $\mathrm{BP}$ & epel & $5-7,10$ \\
\hline C. scutellum & MP & epsm & $1,2,4-6$ & N. sp. C & $\mathrm{BP}$ & epel & 1,5 \\
\hline C. sp. A & MP & epsm & $1,2,6,9,10$ & Nitzschia amphibia & $\mathrm{BP}$ & epel & 3 \\
\hline C. sp. B & MP & epsm & $1,2,7$ & N. angulares & $\mathrm{BP}$ & epel & $3,5,8,10$ \\
\hline C. sp. C & MP & epsm & $3,4,6,7,9$ & N. brevirostris & $\mathrm{BP}$ & epel & 2,14 \\
\hline Coscinodiscus sp. A & C & $\mathrm{p}$ & 3 & N. closterium & $\mathrm{BP}$ & $\mathrm{p}$ & 5,14 \\
\hline Cymatosira belgica & $\mathrm{C}$ & epsm & $2,3,5,7$ & N. constricta & $\mathrm{BP}$ & epel & 4 \\
\hline C. lorenziana & $\mathrm{C}$ & epsm & $1-5,7,8,10$ & N. frustulum & $\mathrm{BP}$ & epel & $1,2,14$ \\
\hline Delphineis karstnii & AP & epsm & 1,5 & N. hybridaeformis & $\mathrm{BP}$ & epel & $1,3,5,10$ \\
\hline D. surrirella & AP & epsm & $1,4,6,10$ & N. incurva & $\mathrm{BP}$ & epel & 3,4 \\
\hline Diploneis aestuarii & $\mathrm{BP}$ & epel & $1-10,12,14$ & N. marginata & $\mathrm{BP}$ & epel & 1 \\
\hline D. bombus & $\mathrm{BP}$ & epel & $5,8-10$ & N. panduriformis & $\mathrm{BP}$ & epel & $1-10,14$ \\
\hline D. chersonensis & $\mathrm{BP}$ & epel & $4,8,10,14$ & N. pellucida & $\mathrm{BP}$ & epel & 1 \\
\hline D. decipiens & $\mathrm{BP}$ & epel & 5,10 & N. sp. A & $\mathrm{BP}$ & epel & $1,5,9$ \\
\hline D. smithii & $\mathrm{BP}$ & epel & $3,7,9$ & N. sp. B & $\mathrm{BP}$ & epel & $3,4,7$ \\
\hline D. sp. A & $\mathrm{BP}$ & epel & 8 & N. sp. C & $\mathrm{BP}$ & epel & 7 \\
\hline Entomoneis kjellmanii & $\mathrm{BP}$ & epel & 1 & N. sp. indeter. & $\mathrm{BP}$ & epel & 9,11 \\
\hline
\end{tabular}


Table 5 (continued)

\begin{tabular}{|c|c|c|c|c|c|c|c|}
\hline Species & Iorphology & $\begin{array}{l}\text { Life } \\
\text { habit }\end{array}$ & Site no. & Species & phology & $\begin{array}{l}\text { Life } \\
\text { habit }\end{array}$ & Site no. \\
\hline Odontella aurita & $\mathrm{C}$ & p/ephy & 6 & $P$. sp. indeter. & BP & epel & 9 \\
\hline Opephora pacifica & AP & es/ep & 1,2 & Thalassiosira decipiens & $\mathrm{C}$ & $\mathrm{p}$ & 9 \\
\hline Paralia sulcata & $\mathrm{C}$ & tpl & 2,12 & T. sp. A & $\mathrm{C}$ & $\mathrm{p}$ & $1,5,6$ \\
\hline Parlibellus adnatas & $\mathrm{BP}$ & epel & 5 & T. sp. B & $\mathrm{C}$ & $\mathrm{p}$ & 5 \\
\hline Petroneis altisima & $\mathrm{BP}$ & epel & 3 & Trachysphenia accuminata & AP & ephy & 1 \\
\hline Pinnularia lanceolata & $\mathrm{BP}$ & epel & 5 & Trachyneis sp. A & BP & epel & 1 \\
\hline$P . \mathrm{sp} . \mathrm{A}$ & $\mathrm{BP}$ & epel & 4 & Triceratium sp. A & & & 13 \\
\hline Plagiogramma pygmaeum & $m \mathrm{C}$ & uben & 1 & Unknown sp. A & & & 1,3 \\
\hline \multirow{2}{*}{$\begin{array}{l}\text { Pleurosigma } \\
\text { distinguendum }\end{array}$} & BP & epel & $5-9,10,14$ & Unknown sp. B & & & 2 \\
\hline & & & & Unknown sp. C & & & 3 \\
\hline P. marinum & $\mathrm{BP}$ & epel & $1,6,13$ & Unknown sp. D & & & 2 \\
\hline$P$. rostratum & BP & epel & 3 & & & & \\
\hline
\end{tabular}

forcing, but do not last long enough to produce significant horizontal transport (Wren \& Leonard 2005). Hurricane Isabel, a Category 2 hurricane, transited the study area approximately 1 mo prior to this sampling effort, 17-18 September 2003, but analyses from moorings in Onslow Bay showed that water transport was primarily southwestward, parallel to the coast and shelf break and reversed rapidly northeastward as the eye of the storm passed the area (Bingham 2007). Near-bottom current velocities and durations appear inadequate to have transported benthic microalgae from shelf habitats into slope habitats. Moreover, persistence of a living benthic microflora in slope habitats more than 1 mo after Hurricane Isabel indicates that off-shelf transport was not the source of the diatom assemblage we describe from this sampling effort. Down-slope mass wasting is probably not significant due to the low gradient in the area $(<4 \%)$, unlike the situation north of Cape Hatteras, where rapid downslope transport of viable diatoms to very deep depths has been documented (Cahoon et al. 1994). Though a slight current affected ROV operations during the 2003 cruise, velocities were not great enough to move sediment $\left(<0.3 \mathrm{~m} \mathrm{~s}^{-1}\right)$, as observed directly in video images obtained by the camera affixed to the ROV (McGee 2005).

Second, a previous finding of enhanced fucoxanthin: chl a ratios of benthic microalgal assemblages from a deep, low light location compared with a shallower location in Onslow Bay suggested either selection for an assemblage with enhanced cellular content of the blue-light harvesting pigment, fucoxanthin, or in situ chromatic adaptation to lower light levels dominated by shorter wavelengths in deeper water (Cahoon et al. 1992). HPLC analyses (Klein \& Sournia 1985) of acetone extracts of sediments collected by divers in

Table 6. Morphometric comparisons of axis lengths of 20 diatom frustules of each species found live at deep sites (D, this study) and 20 frustules of the same species from intertidal habitats (I) in coastal North Carolina (Hilterman 1999) using 1-way ANOVA $(\mathrm{df}=1,38$ for all comparisons; $\mathrm{ns}=$ not significant at $\mathrm{p}<0.05)$. Morphology characteristics: $\mathrm{M}=$ monoraphic, $\mathrm{B}=$ biraphic, $\mathrm{U}=$ unoccluded, $\mathrm{H}=$ hymenate

\begin{tabular}{|c|c|c|c|}
\hline \multirow{2}{*}{$\begin{array}{l}\text { Species } \\
\text { Morphology }\end{array}$} & \multirow{2}{*}{\multicolumn{2}{|c|}{$\begin{array}{l}\text { Axis } \\
\text { Trans-apical }\end{array}$}} & \multirow[b]{2}{*}{ Pervalvar } \\
\hline & & & \\
\hline $\begin{array}{l}\text { Cocconeis disculata } \\
\text { M, U }\end{array}$ & ns & $\mathrm{ns}$ & ns \\
\hline $\begin{array}{l}\text { Fallacia forcipata } \\
\qquad \mathrm{B}, \mathrm{U}\end{array}$ & $\begin{array}{c}\mathrm{D}>\mathrm{I} \\
F=6.39, \mathrm{p}=0.0157\end{array}$ & $\begin{array}{c}\mathrm{D}>\mathrm{I} \\
F=15.63, \mathrm{p}=0.003\end{array}$ & $\begin{array}{c}\mathrm{D}>\mathrm{I} \\
F=9.43, \mathrm{p}=0.0039\end{array}$ \\
\hline $\begin{array}{l}\text { Navicula sp. A } \\
\text { B, U }\end{array}$ & $\begin{array}{c}\mathrm{D}>\mathrm{I} \\
F=11.37, \mathrm{p}=0.0017\end{array}$ & $\begin{array}{c}\mathrm{I}>\mathrm{D} \\
F=17.41, \mathrm{p}=0.0002\end{array}$ & $\begin{array}{c}\mathrm{I}>\mathrm{D} \\
F=13.77, \mathrm{p}=0.0007\end{array}$ \\
\hline $\begin{array}{l}\text { Nitzschia frustulum } \\
\text { B, H }\end{array}$ & $\mathrm{ns}$ & ns & $\begin{array}{c}\mathrm{D}>\mathrm{I} \\
F=13.62, \mathrm{p}=0.0007\end{array}$ \\
\hline $\begin{array}{l}\text { Nitzschia panduriformis } \\
\qquad \mathrm{B}, \mathrm{U}\end{array}$ & $\begin{array}{c}\mathrm{D}>\mathrm{I} \\
F=14.96, \mathrm{p}=0.0004\end{array}$ & $\begin{array}{c}\mathrm{D}>\mathrm{I} \\
F=26.03, \mathrm{p}<0.0001\end{array}$ & $\begin{array}{c}\mathrm{D}>\mathrm{I} \\
F=25.19, \mathrm{p}<0.0001\end{array}$ \\
\hline
\end{tabular}


shallow water $(<35 \mathrm{~m})$ and by ROV in deeper waters yielded mean peak area fucoxanthin:chl a ratios of 1.86:1 ( $\mathrm{n}=3, \mathrm{SD}=0.32$ ) from samples collected at $33 \mathrm{~m}$ with ambient light flux of $81.3 \mu \mathrm{mol}$ photons $\mathrm{m}^{-2} \mathrm{~s}^{-1}$ and 5.08:1 $(\mathrm{n}=5, \mathrm{SD}=0.86)$ from samples collected at $63 \mathrm{~m}$ with ambient light flux of $2.34 \mu \mathrm{mol}$ photons $\mathrm{m}^{-2}$ $\mathrm{s}^{-1}$ (Cahoon et al. 1992). Altered light-harvesting physiology supports the argument for distinct microalgal assemblages, consistent with our taxonomic observations. Such adaptation to life in deep, low-light environments is more likely to confer advantages than the inconsistent patterns of morphometric characteristics observed in benthic diatoms from deep habitats.

The presence of live active diatoms in sediments at depths to $191 \mathrm{~m}$, and at $<0.03 \%$ surface incident radiation, significantly extends the potential limits of benthic primary production. We made a preliminary estimate of potential daily production in the outer continental shelf and upper slope regions of Onslow Bay for the depth range from $41 \mathrm{~m}$, the deepest previous production measurement in Onslow Bay (Cahoon \& Cooke 1992), to $191 \mathrm{~m}$, the new depth limit for benthic microalgal production. Using previous estimates of chl a biomass distribution in this depth range

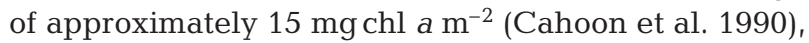
a value for $P^{\mathrm{B}}$ of $0.8 \mathrm{mgC}(\mathrm{mg} \mathrm{chl} \mathrm{a})^{-1} \mathrm{~h}^{-1}$ (Cahoon \& Cooke 1992), and a production day length of $10 \mathrm{~h}$ we derive a value on the order of $120 \mathrm{mg} \mathrm{C} \mathrm{m}^{-2}$. This production estimate is approximately $50 \%$ of the average gross daily benthic production in the portions of Onslow Bay <41 m deep (Cahoon \& Cooke 1992), but the steeper continental margin portion accounts for only $28 \%$ more area than the shelf portion of Onslow Bay (<55 $\mathrm{m}$ deep), yielding an increase in total estimated benthic production for Onslow Bay of $\sim 14 \%$. Extrapolations of benthic microalgal biomass and production to larger scales from Onslow Bay, which has had more thorough spatial sampling than any comparable continental margin ecosystems, are limited by paucity of data (Table 1; Cahoon 1999). Clearly, further study of the depth distributions of living benthic microalgae in continental margin ecosystems is warranted, particularly in light of the contribution to benthic food chains, sediment-water interactions and net carbon fluxes in continental margin habitats this community may support.

Acknowledgements. Use of RV 'Cape Hatteras' was supported by the Duke University and University of North Carolina (UNC) Oceanographic Consortium. Operation of, and support for, the SuperPhantom II ROV was provided by the National Undersea Research Center at UNC Wilmington (NOAA Award \#NA03OAR4300088). We thank L. Horn for ROV operations, M. Gay for graphics and R. Ward for assistance with iLumina. Additional support was provided by the Pilot Project program of the Center for Marine Science at UNC Wilmington.

\section{LITERATURE CITED}

Bingham F (2007) Physical response of the coastal ocean to Hurricane Isabel near landfall. Ocean Sci 3:159-171

Brotas V, Catarino F (1995) Microphytobenthos primary production of the Tagus estuary (Portugal). Neth J Aquat Ecol 29:333-339

Brown RM, Lee GKF, Hulbert AM (1992) Environmental sampling tools designed for use on a low cost remotely operated vehicle (LCROV). In: Cahoon LB (ed) Diving for science. Proc 12th Annu Sci Diving Symp. American Academy of Underwater Sciences, Costa Mesa, CA, p 23-30

Bunt JS, Lee CC, Lee E (1972) Primary productivity and related data from tropical and subtropical marine sediments. Mar Biol 16:28-36

Cahoon LB (1999) The role of benthic microalgae in neritic ecosystems. Oceanogr Mar Biol Annu Rev 37:47-86

Cahoon LB (2006) Upscaling primary production estimates: regional and global scale estimates of microphytobenthos production. In: Kromkamp JC, de Brouwer JFC, Blanchard GF, Forster RM, Creach V (eds) Functioning of microphytobenthos in estuaries. Royal Netherlands Academy of Arts and Sciences, Amsterdam, p 99-108

Cahoon LB, Cooke JE (1992) Benthic microalgal production in Onslow Bay, North Carolina, USA. Mar Ecol Prog Ser 84:185-195

Cahoon LB, Laws RA (1993) Benthic diatoms from the North Carolina continental shelf: inner and mid-shelf. J Phycol 29:257-263

Cahoon LB, Redman RS, Tronzo CR (1990) Benthic microalgal biomass in sediments of Onslow Bay, North Carolina. Estuar Coast Shelf Sci 31:805-815

Cahoon LB, Laws RA, Savidge TW (1992) Characteristics of benthic microalgae from the North Carolina outer continental shelf and slope: preliminary results. In: Cahoon LB (ed) Diving for science. Proc 12th Annu Sci Diving Symp. American Academy of Underwater Sciences, Costa Mesa, CA, p 61-68

Cahoon LB, Laws RA, Thomas CJ (1994) Viable diatoms and chlorophyll $a$ in continental slope sediments off Cape Hatteras, North Carolina. Deep-Sea Res 41:767-782

Charpy-Robaud C, Sournia A (1990) The comparative estimation of phytoplanktonic, microphytobenthic, and macrophytobenthic primary production in the oceans. Mar Microb Food Webs 4:31-57

Dayton PK, Watson D, Palmisano A, Barry JP, Oliver JS, Rivera D (1986) Distribution patterns of benthic microalgal standing stock at McMurdo Sound, Antarctica. Polar Biol 6:207-213

Falkowski PG (1988) Theoretical calculation of the depth of the eupohotic zone in the sea. National Undersea Research program report No. 88-1, Rockville, MD

Falkowski PG, Raven JA (1997) Aquatic photosynthesis. Blackwell Publishers, Malden, MA

Hendey NI (1964) An introductory account of the smaller algae of British coastal waters: Part V: Bacillariophyceae (Diatoms). Her Majesty's Stationery Office, London

Hilterman J (1998) Taxonomic composition, distribution and hurricane effects on diatom assemblages on Masonboro Island, NC. MS thesis, University of North Carolina, Wilmington, $\mathrm{NC}$

Hustedt F (1955) Marine littoral diatoms of Beaufort, North Carolina. Bull Duke Univ Mar Lab, No. 6

John J (1983) The diatom flora of the Swan River Estuary, Western Australia. J Cramer, Vaduz

Johnson Z, Landry ML, Bidigare RR, Brown SL and others 
(1999) Energetics and growth kinetics of a deep Prochlorococcus spp. population in the Arabian Sea. Deep-Sea Res 46:1719-1743

Johnson Z, Bidigare RR, Goericke R, Marra J, Trees C, Barber RT (2002) Photosynthetic physiology and physicochemical forcing in the Arabian Sea, 1995. Deep-Sea Res 49: 415-436

Klein B, Sournia A (1987) A daily study of the diatom spring bloom at Roscoff (France) in 1985. II. Phytoplankton pigment composition studied by HPLC analysis. Mar Ecol Prog Ser 37:265-275

Kühl M, Glud RN, Borum J, Roberts R, Rysgaard S (2001) Photosynthetic performance of surface-associated algae below sea ice measured with a pulse-amplitudemodulated (PAM) fluorometer and $\mathrm{O}_{2}$ microsensors. Mar Ecol Prog Ser 223:1-14

Laws RA (1983) Preparing strewn slides for quantitative microscopical analysis: a test using calibrated microspheres. Micropaleontology 29:60-65

Littler MM, Littler DS, Blair SM, Norris JN (1985) Deepest known plant life discovered on an uncharted seamount. Science 227:57-59

MacIntyre HL, Cullen JJ (1996) Primary production by suspended and benthic microalgae in a turbid estuary: time scales of variability in San Antonio Bay, Texas. Mar Ecol Prog Ser 145:245-268

Editorial responsibility: Otto Kinne, Oldendorf/Luhe, Germany
Markager S, Sand-Jensen K (1992) Light requirements and depth zonation of marine macroalgae. Mar Ecol Prog Ser 88:83-92

McGee DK (2005) Morphologic comparisons of shallow and deepwater benthic marine diatoms of Onslow Bay, North Carolina. MS thesis, University of North Carolina, Wilmington, $\mathrm{NC}$

Meyercordt J, Meyer-Reil LA (1999) Primary production of benthic microalgae in two shallow coastal lagoons of different trophic status in the southern Baltic Sea. Mar Ecol Prog Ser 178:179-191

Plante-Cuny MR (1978) Pigments photosynthétiques et production primaire des fonds meubles néritiques d'une region tropicale (Nosy-Bé, Madagascar). Travaux et Documents de L'ORSTOM 96, Paris

Round FE, Crawford RM, Mann DG (1990) The diatoms: biology and morphology of the genera. Cambridge University Press, New York

Steele JH, Baird IE (1968) Production ecology of a sandy beach. Limnol Oceanogr 13:14-25

Sun MY, Aller RC, Lee C (1994) Spatial and temporal distributions of sedimentary chloropigments as indicators of benthic processes in Long Island Sound. J Mar Res 52: 149-176

Wren A, Leonard L (2005) Sediment transport on the midcontinental shelf in Onslow Bay, North Carolina during Hurricane Isabel. Estuar Coast Shelf Sci 63:43-56

Submitted: August 9, 2007; Accepted: October 15, 2007 Proofs received from author(s): February 26, 2008 